\title{
THE STRUCTURE OF THE RADIATION BALANCE ON A SANDY SURFACE: CASE THE BŁĘDÓW DESERT, SILESIAN UPLAND
}

\section{ZBIGNIEW CAPUTA}

University of Silesia, Faculty of Earth Science, 60 Będzińska Street, 41-200 Sosnowiec, Poland; e-mail: zbigniew. caputa@us.edu.pl

\begin{abstract}
Caputa Z.: The structure of the radiation balance on a sandy surface: case the Błędów desert, Silesian Upland. Ekológia (Bratislava), Vol. 35, No. 2, p. 114-125, 2016.

Comprehensive environmental studies taking under consideration the structure of the radiation balance during the vegetation growing seasons of 2001 and 2002 were carried out on the open sandy surface of the area called the Błędów 'desert' located on Silesian Upland. The research in each site covered the composition of plant species, their age and height, the condition of the substratum, the composition and structure of the soil and the meteorological conditions with elements of the radiation balance. The article presents some part of the research on meteorological elements and their impact on ecosystem. Special attention was devoted to radiation conditions on the open sandy surface in the context of the formation of BSC (biological soil crust). Having presumed that the values obtained on the grassy surface constituted $100 \%$, the values of radiation reflection measured on the open sandy surface were $185 \%$ higher and the values of net longwave radiation were $105 \%$ higher in day time and $137 \%$ in night time. Values of net radiation of about $63 \%$ lower were observed on the sandy surface during a typical sunny summer day. It was found that a strong irradiation of the sandy surface $\left(26 \mathrm{MJ} \cdot \mathrm{m}^{-2} \mathrm{~d}^{-1}\right)$ creates extremely difficult conditions for the initiation of the process of ecosystem formation (including BSC or plant succession). The elements of the radiation balance, net radiation, albedo and temperature of the open sandy surface were represented quantitatively. The test surfaces were classified based on the value of the albedo: group I with low albedo values, up to 0.15 (spore-bearing plants on a dark surface), including BSC; group II with mean values of the albedo from 0.16 to 0.24 (spore-bearing plants and seed on a dark grey surface); and group III with high albedo values, above 0.25 (plants growing on bare or loose sands).
\end{abstract}

Key words: radiation balance, albedo, ecosystem, microclimate, sand surface, Silesian Upland.

\section{Introduction}

The process of the supply, transformation and exchange of energy that occurs on the boundary layer between the atmosphere and the ground surface is a key factor determining climatic conditions (Oke, 1999). The exchange and transformation of energy occurs within the active layer, the thickness and character of which largely depend on vegetation (Paszyński et al., 1999). The active layer of the surface devoid of vegetation or with initial vegetation is extremely sensitive to changes in solar radiation (Caputa, Wojkowski, 2013, Huia et al., 2013). The open sand surface is 
an example of such a surface. The contrast in the climate and landscape of different desert areas was the subject of numerous works: from the plant succession (Fromm et al., 2000), the development of species, to the indication of climatic factors, water availability, and so on as the elements that determine the changes in the surface of the desert; the occurrence of dew (Kidron, 2010); the formation of soil; the biological soil crust (BSC) communities consisting of surface soil-dwelling cyanobacteria, green algae, microfungi, bacteria, lichens and bryophytes (Belnap et al., 2003); temperature on microbiotic sand crusts (Kidron et al., 2010); and plant ecology. A crucially important to ecology is recognising the conditions of the process of the formation of plant-soil cover on sandy surfaces (Bednarek et al., 2002). The development of soil is conditioned not only by the climatic factors, bedrock and topography but also by the vegetation and activity of living organisms ( $\mathrm{Li}$ et al., 2010). Works that analyse the structure of the radiation balance on initial surfaces for plants (e.g. sandy surface) are scarce. Understanding the radiation balance on these surfaces may cast new light on studies related to the colonisation of deserts (Kidron et al., 2014) of postindustrial areas (Czylok, Rahmonov, 2004; Czylok et al., 2008), post-sand excavations (Rahmonov, Szymczyk, 2010) and the formation of BSC (Cabała, Rahmonov, 2004). On the other hand, the diverse supply of irradiation to the active layer of the surface, which results from topography, or an increase in infrared radiation may affect the process of the communities formation in sandy ecosystems, poor in nutrient compounds (Rahmonov et al., 2004). Moreover, it may also have important implications for the colonisation of the land and soil, as well as shaping geochemical processes in the progressive climate warming.

The presence of the open sandy surface in Silesian Upland enables the exploration of ecological determinants of the communities typical of sandy areas. The field studies of the area were focused on changes in the distribution of vegetation (Nowak et al., 2011), plant succession (Rahmonov, Kin, 2007), the formation of soil and vegetation (Bednarek et al., 2002; Rahmonov et al., 2004), cyanophyta and algae as an important component of BSC (Cabała, Rahmonov, 2004), communities formation in varied topography (Rahmonov et al., 2002) and the change under anthropopressure (Tyc et al., 1999; Czylok et al., 2008). An attempt was also made to determine the characteristics defining surfaces according to radiation, that is albedo ( $\alpha$ ), long-wave exchange and radiative efficiency coefficients (Caputa, 2007). However, climatic factors that inhibit fouling of open sandy surfaces and the formation of ecological system (e.g. irradiation, UV) were not studied. In this paper, special attention has been focused on the structure of the radiation balance on the sandy surface. Abiotic factors (e.g. irradiation) determine the features of the sandy surface, for example, distribution of moisture, BSC (Kidron et al., 2010) and the succession of plants (Rahmonov, 2007), whereas ultraviolet (UV), particularly UV-B, is extremely harmful to living organisms ( $\mathrm{Li}$ et al., 2014). Therefore, the aim of this study was to determine the structure of the radiation balance as an important factor for the formation of the plant-soil cover and vegetation growing on open sandy areas both natural and anthropological.

\section{Study area and methods}

Site description

Resulting from the exploitation of sand or other materials, large sandy areas of Silesian Upland are deprived of soil cover down to the bedrock (Szczypek, Wach, 1999). For this reason, the initiation of plant succession or soil devel- 
opment is impeded. The study area was located in an area of Vistulian glaciofluvial and fluvial sands in the eastern Silesian Upland (Fig. 1). The exploitation of sand, the occurrence and dynamics of the open sandy surface were well documented (Pełka-Gościniak et al., 2007; Machowski, 2010), together with the description of the soil and vegetation by Rahmonov (2000, 2007).

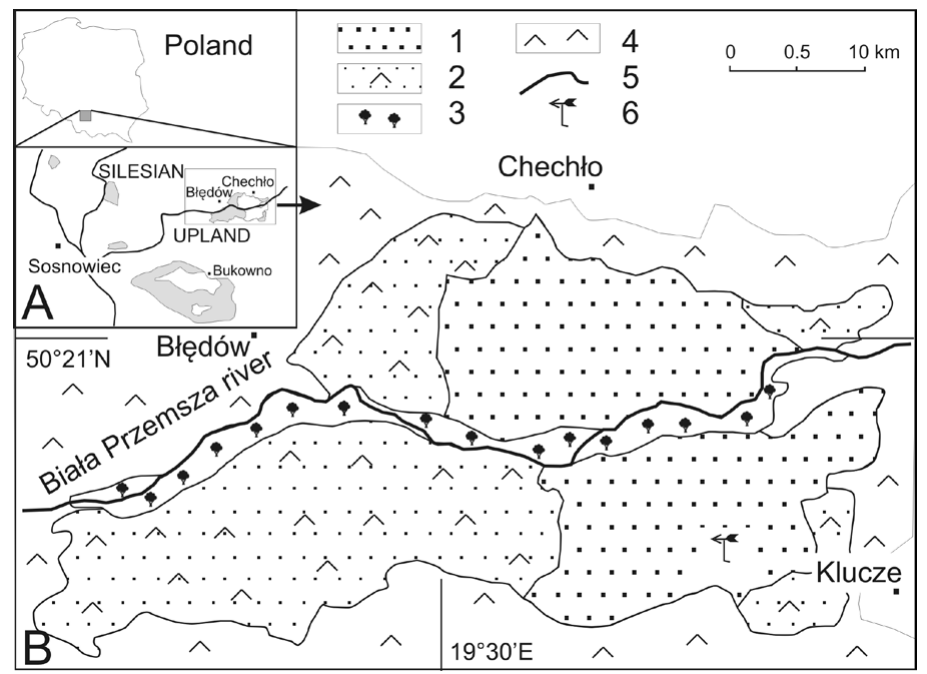

Fig. 1. The study area (A) some sand excavation in Silesian Upland, (B) Błędów "desert" 1 - bare sand and initial communities, 2 - initial pine coniferous forest, 3 - riverside carrs and hygrophilous communities, 4 - mixed forest, 6 - meteorological station.

The climate of the test area does not reveal more severe thermal and humidity characteristics than of the adjacent areas. The annual course of air temperature was typical for a temperate and transitional climate. The average monthly temperature during the period $1961-1990$ ranged from $-3.0^{\circ} \mathrm{C}$ in January to $17.3^{\circ} \mathrm{C}$ in July. The average annual temperature in the multi-year test period was $7.8^{\circ} \mathrm{C}$ and varied from 6.6 to $9.2^{\circ} \mathrm{C}$ in particular years, showing an upward trend. For the period 1951-2005, an increase in air temperature was recorded over the past two decades (Michalska, 2011). The number of hot days ( $\operatorname{Tmax}>25^{\circ} \mathrm{C}$ ) increased by up to 4.6 days $/ 10$ years (Kejna et al., 2014). Precipitation in the central part of Silesian Upland did not exceed $700 \mathrm{~mm}$ per year. The average cloud cover was $63 \%$; the number of sunny days was 53 and cloudy days was 114 . The annual average relative air humidity in this multi-year period was $77 \%$, varying from $82 \%$ in winter to $72 \%$ in the warm season (Kruczała, 2000).

The above figures, therefore, do not determine climatic creation of a desert. The causes of the occurrence of open sandy surfaces should be sought in anthropogenic factors associated with the development of non-ferrous extractive metallurgy in the twelfth, and then in the sixteenth and seventeenth centuries. This resulted in the deforestation of the area, and thus the launch of aeolian processes in the area between Błędów and Klucze (Pełka-Gościniak et al., 2007).

\section{The location of the meteorological station of the University of Silesia in Sosnowiec}

Sosnowiec is situated in the eastern part of Silesian Upland heavily transformed by man. Extensive changes in the spatial development took place there due to the concentration of industry and urban development, which brought about an increase in atmospheric pollution. This had a significant impact on the average daily total of the incoming short-wave radiation (K) in the years 1960-1980. The annual average daily total $\mathrm{K} \downarrow$ amounted to $9.0 \mathrm{MJ} \cdot \mathrm{m}^{-2} \mathrm{~d}^{-1}$ in the area of Silesian Upland and increased to $10.0 \mathrm{MJ} \cdot \mathrm{m}^{-2} \mathrm{~d}^{-1}$ in Cracow Upland (Paszyński, Miara, 1994). After the period of the political system transition, there was a reduction in pollution and improvement in the air quality. The average value of the daily total $\mathrm{K} \downarrow$ in the multi-year tested period 2000-2009 was $10.3 \mathrm{MJ} \cdot \mathrm{m}^{-2} \mathrm{~d}^{-1}$ (Caputa, Leśniok, 2011). Similar conditions of insolation

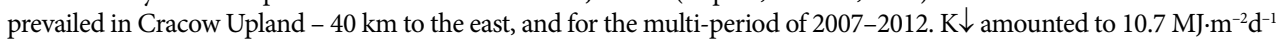


(Caputa, Wojkowski, 2015). The fact that the distance between the station of the University of Silesia and the study area is short and the irradiation therein is similar enables comparing the structure of the radiation balance for these two surfaces.

\section{Meteorological measurements}

The presented study had been planned for the open sandy surface during sunny days in order to observe the greatest contrasts in radiation throughout the day. The measuring station was located on the surface of the deflation surface (50²0'13 “N, 19³1'50" E $318 \mathrm{~m}$ m.s.l.) in the eastern part of Silesian Upland (Fig. 1). The measurements were carried out in the growing season on selected plant communities for a few days, and further ecological observations were made systematically in selected organic transects (Rahmonov et al., 2002). The measurements of the radiation balance components were conducted in the period of 17-19 May, 2000 for the deflation surface and 2-3 August, 2001 for the surface covered with xerothermic vegetation and a pine thicket. Furthermore, at these points, the measurements of the reflected radiation (pyranometer SP1100 Skye) and point-measurements of the temperature of the surface and ground at a depth of $-5 \mathrm{~cm}$ with a thermometer TP-411 Elmetron were made.

The station was equipped with a logger CR23X by Campbell and sensors of humidity (HMP45C profile 50, 200 cm), thermal profile $(-5,0,50,200 \mathrm{~cm})$, wind speed and direction and a radiometer (CNR1 - Kipp\&Zonen at an altitude of $150 \mathrm{~cm}$ ). At a distance of $30 \mathrm{~km}$, in the suburban area, in analogical station of the University of Silesia, a set of sensors recorded values for the grassy surface ( $50^{\circ} 17^{\prime} 54^{\prime \prime} \mathrm{N}, 19^{\circ} 07^{\prime} 57^{\prime \prime} \mathrm{E} 363 \mathrm{~m} \mathrm{~m} . \mathrm{s} .1$.). The vicinity of the station is dominated by low buildings and allotments; therefore, covering of the horizon is marginal.

The radiation balance comprises elements of shortwave radiation, the source of which is the sun, and longwave radiation, which represents the radiation of the Earth's surface and atmosphere:

$\mathrm{Q}^{*}=\mathrm{K}^{*}+\mathrm{L}^{*}=(\mathrm{K} \downarrow-\mathrm{K} \uparrow)+(\mathrm{L} \downarrow-\mathrm{L} \uparrow)$

where $\mathrm{Q}^{*}$ is the net radiation, net all-wave radiation flux density; $\mathrm{K}^{\star}$ is the absorbed solar radiation, net shortwave radiation; $\mathrm{L}^{*}$ is the net longwave radiation, $\mathrm{K} \downarrow$ is the global solar radiation, incoming shortwave radiation; $\mathrm{K} \uparrow$ is the reflected solar radiation; $\mathrm{L} \downarrow$ is the atmospheric counter radiation, incoming longwave radiation and $\mathrm{L} \uparrow$ is the outgoing longwave

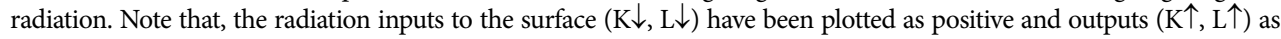
negative to aid the interpretation of the radiation balance.

\section{Meteorological conditions during the research}

The research was conducted on 17 May, 2000. It was a clear day, sunrise occurred at 4:53 and sunset at 20:28; the daytime amounted to $15 \mathrm{~h}$ and $35 \mathrm{~min}$. The potential supply of solar energy at the moment of the sun culmination was $1191 \mathrm{~W} \cdot \mathrm{m}^{-2}$. During the fieldwork, the study area was within the range of an anticyclone with warm air mass. A typical summer day was characterised by the low cloud cover (cumulous clouds appeared in the afternoon) and high temperature values, maximum of $28.7^{\circ} \mathrm{C}$ and minimum of $7.2^{\circ} \mathrm{C}$. A low wind speed of a daily average of $1.5 \mathrm{~m} / \mathrm{s}$ was recorded, and a maximum wind gust of 4.0 $\mathrm{m} / \mathrm{s}$ occurred in the afternoon. The humidity was variable, from $92 \%$ in the morning (haze) to about $20 \%$ from 11 to 19 hours, with a minimum of $18 \%$ at 15 hour (LT local daylight saving time $=$ UTC +2 hours) (Fig. 2).
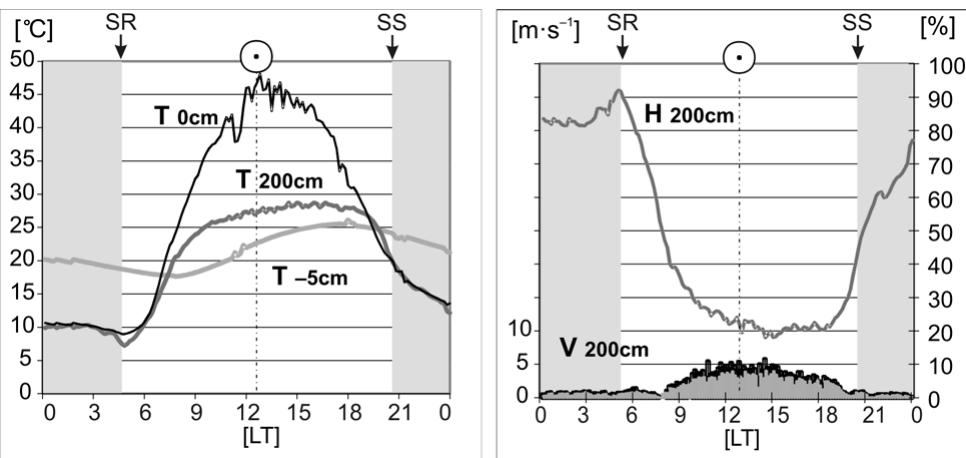

Fig. 2. The daily course of air temperature $\left(\mathrm{T}_{200 \mathrm{~cm}}\right)$, surface $\left(\mathrm{T}_{0 \mathrm{~cm}}\right)$ and ground temperature $\left(\mathrm{T}_{-5 \mathrm{~cm}}\right)$, humidity $\left(\mathrm{H}_{200 \mathrm{~cm}}\right)$, gusts and 10 minutes mean wind velocity $\left(\mathrm{V}_{200 \mathrm{~cm}}\right)$ - deflation surface on 17.05.2000. 


\section{Results}

\section{The structure of the shortwave radiation balance}

During the analysed day, the course of flux $\mathrm{K} \downarrow$ reflected the changes in the altitude of the Sun above the horizon above the grassy (University of Silesia) and sandy surface. About $0.5 \mathrm{MJ} \cdot \mathrm{m}^{-2}$ smaller daily total at the University of Silesia station resulted from the suburban characteristics (Kejna et al., 2014). The ratio of UV radiation in flux K $\downarrow$ was not investigated; nevertheless, a high daily total of the flux $\left(26.0 \mathrm{MJ} \cdot \mathrm{m}^{-2}\right)$ testified to the intense irradiation and UV-B was
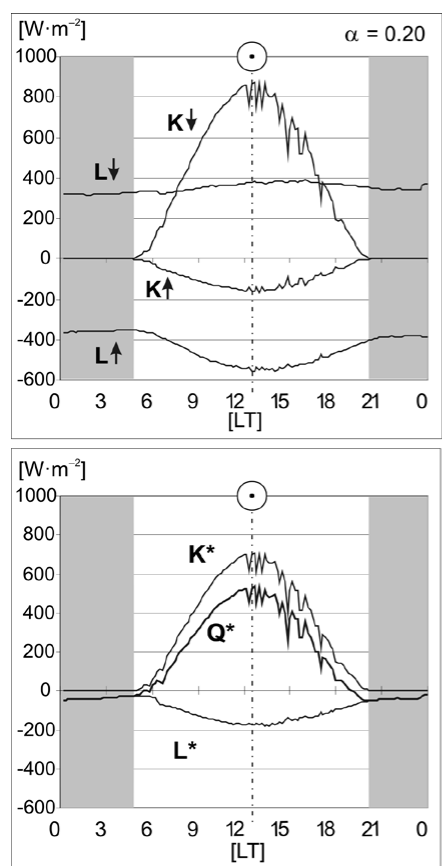

Fig. 3. The daily course of radiation - grassy surface, the University of Silesia (left), and the deflation surface - open sandy surface (right) on 17.05.2000. Albedo in marked as $\alpha=\mathrm{K} \uparrow / \mathrm{K} \downarrow$.
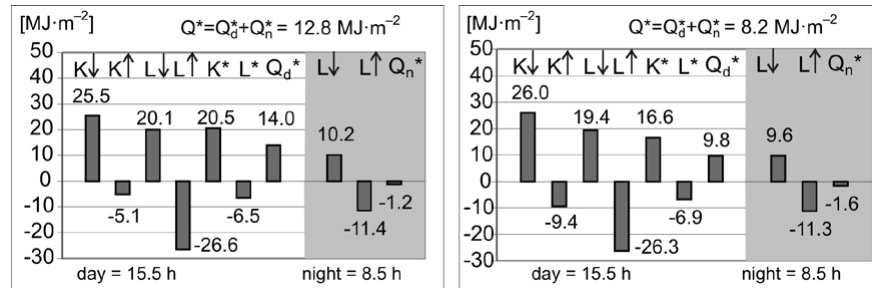

Fig. 4. The structure of the radiation balance - the grassy surface (left) and the deflation surface (right) on 17.05.2000. approximately $1.5 \%$ of flux $\mathrm{K} \downarrow$ (Hollòsy, 2002). It easily destroyed proteins, DNA and other biological molecules (Wolf et al., 2010). Much of this radiation was reflected from the sand because of a high $\alpha$, whereas a lower a was the characteristic of the grassy surface, which was confirmed by the course of flux $\mathrm{K} \uparrow$ (Fig. 3). The studied sandy surface was characterised by a high intensity of flux $\mathrm{K} \uparrow$ reaching up to even $344 \mathrm{~W} \cdot \mathrm{m}^{-2}$. This surface both received a large amount of radiation and reflected it intensely (Fig. 4); therefore, the net $\mathrm{K}^{\star}$ was surprisingly low $\left(16.6 \mathrm{MJ} \cdot \mathrm{m}^{-2}\right)$, 19\% lower than the daily total of net $\mathrm{K}^{\star}$ of the grassy surface. What was the reason for such a high temperature $\left(48.1{ }^{\circ} \mathrm{C}\right)$ of the deflation surface? It resulted from the properties of the test surface (dry, sandy, no high vegetation; there was only a layer of algae 
and cyanobacteria in the form of a light grey crust). The structure of the surface was even better documented on a high magnification (Rahmonov, Piątek, 2007), where grains of sand are bound by the ingredients (algae, cyanobacteria) forming sandy initial ecological system. The daily total of flux $\mathrm{K} \uparrow$ was $9.4 \mathrm{MJ} \cdot \mathrm{m}^{-2}$, and it was $85 \%$ higher than the corresponding total for the measurements on the grassy surface (Fig. 4). Such a structure of the shortwave radiation balance with intensive irradiation (including UV) led to the degradation of algae and cyanobacteria and caused heating up of the surface of the sand, thus impeding life processes of initial plants. The characteristics of the sandy surface determined the values of the net $\mathrm{K}^{\star}$ lower than

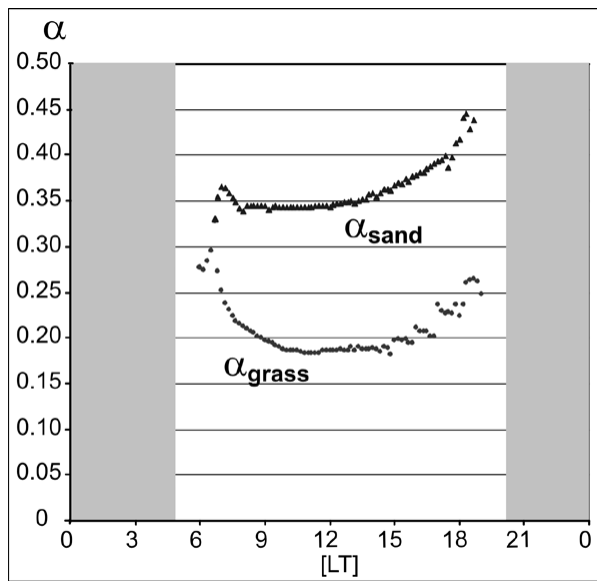

Fig. 5. Albedo ( $\alpha$ ) - the deflation surface (index 'sand') and the grassy surface (index 'grass') on 17.05.2000. the corresponding values for the grassy surface. In addition, other studies of the energy balance show that the vast part of flux $\mathrm{K} \downarrow$ (approximately 60\%) was used for the purpose of evaporation (Paszyński et al., 1999). Similarly, the deflation surface received a relatively small amount of energy that could, amongst others, penetrate deeper layers of the sand through molecular conductivity. This was confirmed by measurements of the temperature of the sand - surprisingly low values of high inertia at a depth of merely $-5 \mathrm{~cm}$, where the maximum was recorded not earlier than at 18:00 LT (Fig. 2).

High values of net $\mathrm{K}^{\star}$ were typical of a sunny day of May. The net $\mathrm{K}^{\star}$ reached a maximum of $710 \mathrm{~W} \cdot \mathrm{m}^{-2}$ for the grassy surface and much lower $\left(597 \mathrm{~W} \cdot \mathrm{m}^{-2}\right)$ for the sand during the ascendancy of the sun (10:40 UTC). This was due to the relatively large $\alpha$ of the sand; its values were variable during the day because of the angle of incidence and cloud cover in the afternoon hours (Fig. 5).

\section{Ecosystem and albedo}

The albedo is the most widely used measure of the active surface features. Owing to the easy determination of the $a$ (measurement of the incoming shortwave radiation and reflected solar radiation with a pyrometer) and its size - not exceeding the unit of 1 - it may be a comparative variable of surfaces. Moreover, the $\alpha$ has been recognised as a major factor that influences surface temperatures and surface biophysical properties (Gómez-Heras et al., 2006). The a determines how much of the heat that reaches the surface in the form of radiation will remain available.

Surfaces and vegetation of the studied open sandy surface is characterised by a relatively high a changeability - from 0.12 to 0.40 (Figs 6 and 7). Withered, dry and dark-coloured vegetation reached a low a value, whilst the highest values were characteristic of sandy, natural (deflation surface) as well as anthropogenically transformed (sand road) surfaces. Dry sand of the deflation surface intensely reflected sunlight ( $\alpha=0.36$ ), whereas the measurements on the sandy substratum (the surface where the upper layer had been removed - light sand) reached an even 


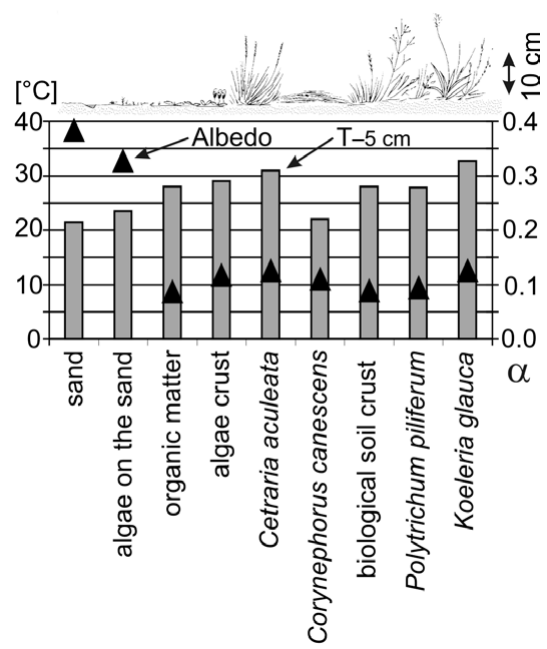

Fig. 6. The ground temperature $(-5 \mathrm{~cm})$ and albedo $(\alpha)$ of the selected surfaces which were measured about midday on a fine day of 2.08.2001.

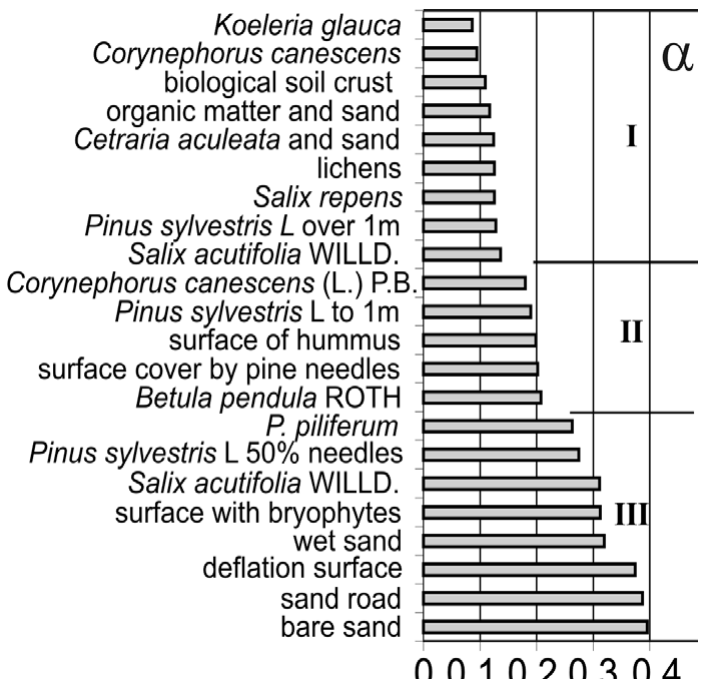

Fig. 7. The albedo $(\alpha)$ of the selected open sandy surfaces which were measured about midday on a fine day of 2.08.2001.

higher a equal to 0.39 (Oke (1999) claims even 0.45!). The cover of the surface, as aforementioned, conditioned the net $\mathrm{K}^{\star}$ and affected the amount of the heat flux in the soil. The intensity of the flux was expressed by the value of the ground temperature (Fig. 6). Only the surfaces of sand and covered with algae reached high temperatures $\left(32-37^{\circ} \mathrm{C}\right)$, whereas initial vegetation, turf and BSC greatly modified the temperature distribution. This was the result of slight shading, persistent moisture of the soil and dew, as the research of the Negev Desert indicates (Kidron, 2010), and due to the absorption of the radiation by plants for their life processes. A high correlation $\left(\mathrm{r}^{2}=0.76\right)$ between the temperature of the ground $(-5 \mathrm{~cm})$ and the $\alpha$ of the sandy surface was affirmed, and the regression equation $\mathrm{T}_{-5 \mathrm{~cm}}=32.2-28.2 \cdot \alpha$ on Silesian Upland was determined (Caputa, 2007). Owing to a large impact of irradiation on ecosystem, the test surfaces have been classified into three groups according to the value of $\alpha$ (Fig. 7).

Group I with low values of $\alpha$ - up to 0.15 - comprises surfaces and plants well adapted to dry and warm conditions (spore-bearing plants on a dark substratum). These biota have adapted to the extreme thermal and radiation conditions. Favourable climate conditions occur in the shade of shrubs and trees, for example, under the branches limiting the flow of radiation to the surface. Mature plants were conducive to the formation of a humus layer of dry leaves, twigs and grass (they withered and their biomass decomposed). Interesting was including into this group BSC as a dark surface with a thin but consolidated layer of humus and strong binding of sand by algae and cyanobacteria. This demonstrates the ecological adaptation of initial plants colonising sands (Rahmonov, Piątek, 2007). On the other hand, a low a and a high net $\mathrm{K}^{\star}$ cause strong heating of these surfaces (Fig. 6) and large thermal contrasts between the day and night (the emission $\mathrm{L} \uparrow$ ).

Group II with the $\alpha$ average values from 0.16 to 0.24 consists of sandy surface with young trees (pine, birch up to $1 \mathrm{~m}$ of height) and other spore-bearing plants on a dark grey substratum, par- 
tially covered with needles and dead organic matter. This group was dominated by plants adapted to high irradiation (white bark, waxy needles, white coating on a sharp-leaf willow (Salix acutifolia), etc.). They often occur in groups of plants in the form of an island of thickets on the sandy substratum. There was a smaller share of complexes of grass or spore-bearing plants in this group.

Group III with high values of $\alpha$ - above 0.25 -comprised of open sandy surfaces of the study area with plants growing on bare or loose sands. The maximum a has been defined for mechanically exposed sand (0.39). In contrast, the natural deflation surface, loose sands and a substratum with bryophytes determined the lower $\alpha(0.32-0.37)$. The surfaces were characterised by an initial stage of plant succession and formation of ecosystem (sand is bound by algae and cyanobacteria).

The irradiation of the open sandy surface was crucial for the formation of the early stages of succession and preservation of communities. Extensive insolation destroys species that were unadapted to intensive UV. The irradiation causes evaporation and water shortages in the summer, which was confirmed by other studies of desert areas (Kidron, 2010). Thermal regime leaded to the rearrangement of the species in communities of sandy surfaces during the summer period. Therefore, algae and cyanobacteria couldn't withstand extreme conditions on the open sandy surface. The ecological role of these species consisted in the initiation of sand biding processes. Extremely important in this group was Polytrichum piliferum (0.26), which has the ability to bind and consolidate sand by rhizoids (Cabała, Rahmonov, 2004). The initial information of the pioneer role of the algae stage in the initiation of soil formation processes at excavations after sand exploitation was also reported by Czylok et al. (2008).

\section{The structure of the longwave radiation balance}

The daily course of flux $L \downarrow$ was similar for both stations. Maximum values of this flux occurred in the afternoon and at the station of the University of Silesia and on the sand amounted to 391 and $380 \mathrm{~W} \cdot \mathrm{m}^{-2}$, respectively. At the university station, higher values of flux $\mathrm{L} \downarrow$ were recorded at night, which was connected with the influence of the characteristics of the suburb on the temperature of the low layers of the atmosphere. During the day, high emission values of both grassy and sandy surfaces were observed. The daily asymmetry flux L $\uparrow$ occurred, reaching even $560 \mathrm{~W} \cdot \mathrm{m}^{-2}$ of the sand in the afternoon despite the cumulous cloud cover. The nocturnal net radiation for the hours between sunset and sunrise $\left(\mathrm{Q}_{\mathrm{n}}{ }^{*}=\mathrm{L} \downarrow-\mathrm{L} \uparrow\right)$ calculated for the sand was 1.7 $\mathrm{MJ} \cdot \mathrm{m}^{-2}$. The character of the longwave radiative heating and cooling was associated with the open space of a large sky view factor - SVF (Oke, 1999; Kidron, 2010), transparency of the air and so on. A high intensity of net $\mathrm{K}^{\star}$ contributed to a high temperature of the sand surface and related significant values of flux $\mathrm{L} \uparrow$. The comparison of the daily courses of the net $\mathrm{K}^{\star}$ and net $\mathrm{L}^{\star}$ explained the reason for the strong heating of the sandy surface (Fig. 3) and then the outgoing nocturnal longwave radiative cooling. The course of the values of net $\mathrm{L}^{*}$ corresponded to slow changes in the temperature of the sand and the adjacent air layer.

\section{The structure of the all-wave radiation flux density balance}

The course of daily net all-wave radiation flux density was noteworthy. Negative values of the net $\mathrm{Q}^{*}$ occurred at night. Negative net $\mathrm{Q}^{*}$ was observed 1.5 hours before sunset for the sandy surface, 
and merely 1 hour for the grassy surface, and also up to 1 hour after sunrise for both studied surfaces. This indicates an intense longwave radiative heating and cooling of the open sandy surface in the afternoon, despite the fact that the daytime values of the analysed net radiation of the sand were on an average $55 \mathrm{~W} \cdot \mathrm{m}^{-2}$ lower than the corresponding values of net $\mathrm{Q}^{*}$ of the grass (Fig. 3 ). The largest differences were observed in the morning - they reached $150 \mathrm{~W} \cdot \mathrm{m}^{-2}$ (the differences resulting from progressive cloudiness were omitted). Persistent large differences between the tested surfaces issued from the aforementioned SVF of the open area, and the features of the sandy surface devoid of vegetation (i.e. light colour, low heat capacity, low roughness, etc.) - high flux $\mathrm{K} \uparrow$, low net $\mathrm{K}^{\star}$ and emission $\mathrm{L}^{\star}$ (Fig. 4). This was confirmed by the results for arid areas of Alma-Ata: relatively low values of the net $\mathrm{Q}^{*}$ during the day, whilst in the afternoon and at night, there was intense emission of the heat accumulated during the day by the substratum (Paszyński et al., 1999).

The total of the daily net $\mathrm{Q}^{*}$ (for the sandy surface) was $8.1 \mathrm{MJ} \cdot \mathrm{m}^{-2}$, which made up $63 \%$ of the net $\mathrm{Q}^{*}$ for the grassy surface during the time of the measurements. Such a large difference resulted from the $\alpha-a$ high reflectivity of the open sandy surface with regard to UV and its high longwave emission. Higher values of the daily net radiation $\left(\mathrm{Q}_{\mathrm{d}}{ }^{*}\right)$ for the grassy surface pointed to the processes of photosynthesis, evaporation, heating plants and soil, evapotranspiration, etc. On the other hand, the negative net $\mathrm{Q}_{n}{ }^{*}$ of the sandy surface during the night time resulted from the intense nocturnal outgoing longwave radiative cooling and lower sky emissivity (L $\downarrow$ ) above the sandy areas of Silesian Upland.

\section{Discussion}

The analysis of the structure of the radiation balance in the all-wave radiation flux density indicated differences between the grassy and sandy surfaces of Silesian Upland (Fig. 4). The largest differences were observed in flux $\mathrm{K} \uparrow$ and net $\mathrm{K}^{\star}$, smaller discrepancy occurred at night with regard to longwave radiation. Intensive irradiation (including UV) of the deflation surface impeded colonisation of the open sandy surface by algae and cyanobacteria (additional factors were high temperature, high soil heat flux, intensive evaporation of the surface). Several studies have revealed that UV-B radiation induces degradation of physiological activity and enhancement of the oxidative stress in higher plants and some cyanobacteria (Xie et al., 2009). Extreme microclimate conditions of the open sandy surface and the lack of fertile ground favoured plants with low ecological requirements. Initial plants (algae, cyanobacteria) influenced the formation and development of soil in poor sandy habitats by consolidating loose surfaces (Rahmonov, Piątek, 2007) and started spontaneous regeneration of vegetation-soil cover occurs (Rahmonov, Szymczyk, 2010). Therefore, the hanging (Rahmanov, Kim, 2007) and topographic (Kidron, 2010) effects together with conditions of smaller radiation and thermal contrasts (Rahmonov et al., 2002) were conducive to plant succession in the further stage of development.

The values of flux $\mathrm{K} \uparrow$, net $\mathrm{K}^{*}$ and $\alpha$ characterised very well the test surfaces. These values and strong relationships between them were determinants of changes taking place on the surface (further stages of initial succession) and communities. Not only did these changes modify flux $\mathrm{K} \uparrow$ but also directly affect the value of net $\mathrm{K}^{*}$ and significantly changed the value of net $\mathrm{Q}^{*}$ (Caputa, 2007). Thermal properties of the open sandy surface depended on its emissivity, thermal conductivity and heat capacity, whereas its radiative cooling power depends, on the one hand, 
on its surface properties (roughness, coating, colour) and, on the other hand, on the sky emissivity. Unlike on different types of relief, the sky emissivity on the open sandy surface was undisturbed (Caputa, Wojkowski, 2015). And as far as the radiative balance was concerned, the sky emissivity was partially or wholly replaced by the obstacle emissivity.

The considerable difference in the values of net $\mathrm{Q}^{*}$ between the grassy and sandy surfaces on a sunny day amounted to $4.7 \mathrm{MJ} \cdot \mathrm{m}^{-2}$. This means that the active layer (University of Silesia) with a very well formed humus layer has the capacity to absorb and use irradiation for the purpose of various biotic and abiotic processes $\left(12.8 \mathrm{MJ} \cdot \mathrm{m}^{-2}\right)$. Features of the active layer of the deflation surface of little roughness, bright and dry substratum, poorly developed initial vegetation and so on manifest otherwise, absorbed a total of $63 \%$ of the daily value of net $Q^{*}$ of the grassy surface (Figs 4,8). Despite this observed relationship between test surfaces (Fig. 9), it is expressed in the regression equation $\mathrm{Q}^{*}$ sand $=$ $-20.52+0.77^{\star} \mathrm{Q}^{\star}$ grass. The values obtained for the grassy surface at the University of Silesia on 17 May, 2000, were assumed as 100\%. Diurnal and nocturnal fluxes and net radiations $\mathrm{Q}_{\mathrm{d}}{ }^{*}$ and $\mathrm{Q}_{\mathrm{n}}{ }^{*}$ were distinguished.

However, even slight unevenness of the terrain, such as sand dunes and phytogenic hills and associated soil, induce differences in microclimate and various settlement strategies (Rahmonov et al., 2002). The explanation for this lies in the differences in irradiation related to the aspect and angle of the slope. Irradiation, in turn, explains thermal differences, as it was indicated by some studies of other areas with diversified relief (Caputa, Wojkowski, 2015). They may also explain the differences in evaporation of the surface (Kidron, 2010). On the other hand, sands covered with vegetation have different $\alpha$ and net $\mathrm{K}^{\star}$. Therefore, even slight changes in the composition of species are responsible for the change in BSC colour and its thickness, and thus the $\alpha$. In this way, the upper surface of BSC has a dark pigment, which protects it from radiation. The analysed sandy surface has a typical structure of the radiation balance. It is highly insolated but simultaneously strongly radiates, which brings about contrasts in radiation, thermal conditions and others. This is an area of high ecological requirements for colonisation by plants. Therefore, detailed information about radiation balance enables better understanding of ecological conditions of sandy surfaces - both natural and anthropogenic, on Silesian Upland. 


\section{Conclusion}

The research on the all-wave radiation balance components of the open sandy surface showed great changeability of the structure of radiation balance in comparison to the grassy surface. Assuming that the values measured on the grassy surface constitute $100 \%$, it was found out that the values of flux $\mathrm{K}^{\uparrow}$, net $\mathrm{L}^{*}$ and the nocturnal net radiation $\left(\mathrm{Q}_{n}{ }^{*}\right)$ for the deflation surface were higher, $185 \%, 105 \%$ and $137 \%$ respectively. Much lower values of diurnal net $\mathrm{Q}_{d}^{*}$ and daily net $\mathrm{Q}^{*}$ were observed on the sandy surface during a sunny day, 70 and $63 \%$, respectively. It was asserted that intensive irradiation of the deflation surface $\left(26.0 \mathrm{MJ} \cdot \mathrm{m}^{-2} \mathrm{~d}^{-1}\right)$ created extremely difficult conditions for the initiation of ecological system as biological soil crust and was the direct cause of algae and cyanobacteria dying and their decomposition in the early summer. On the other hand, the differences in abiotic conditions will affect further development of the succession of other components of the environment.

The open sand surface was characterised by a high reflectance of shortwave radiation and the emission of longwave radiation. Therefore, the test components were different for the researched communities. High values of $\alpha$ and a low net $\mathrm{K}^{\star}$ were essential for the formation of the early stages of succession and preservation of communities. That is why the test surfaces were classified according to the value of the albedo: group I with low albedo values up to 0.15 (spore-bearing plants on a dark substratum) including the biological soil crust, group II with mean values of albedo from 0.16 to 0.24 (spore-bearing and seed plants on a dark grey substratum) and group III with high albedo values above 0.25 (plants growing on bare or loose sands).

\section{References}

Bednarek, R., Dziadowiec, H. \& Pokojska U. (2002). Pedological aspect of variability. Ecol. Quest., 1, 35-41.

Belnap, J., Büdel, B. \& Lange O.L. (2003). Biological soil crust: Characteristics and distribution. In J. Belnap \& O.L. Lange (Eds.), Biological soil crusts: Structure, function, and management. Ecol. Stud., 150, 3-30. DOI: 10.1007/978-3-64256475-8.

Cabała, J. \& Rahmonov O. (2004). Cyanophyta and algae as an important component of biological crust from Pustynia Błędowska Desert (Poland). Pol. Bot. J., 49(1), 93-100.

Caputa, Z. (2007). Diversity of albedo and longwave exchange and radiative efficiency coefficients on the Błędów Desert area (in Polish). Pamiętnik Puławski, 144, 35-44.

Caputa, Z. \& Leśniok M. (2011). Incoming shortwave solar radiation in Sosnowiec (2000-2009) (in Polish). Prace i Studia Geograficzne, 47, 393-400.

Caputa, Z. \& Wojkowski J. (2013). Influence of solar radiation on air and soil temperature in the Cracow Upland (in Polish). Pradnik Prace i Materiały Muzeum im. prof. Władysława Szafera, 23, 65-74.

Caputa, Z. \& Wojkowski J. (2015). Structure of radiation balance in diverse types of relief. Annals of Warsaw University of Life Science, Land Reclamation, 47(4) 343-354. DOI: 10.1515/sggw-2015-0036.

Czylok, A. \& Rahmonov O. (2004). The encroachment of Scots pine Pinus sylvestris L. on the area of former sand exploitation in the eastern Silesian Upland. In A. Brzeg \& M. Wojterska (Eds.), Coniferous forest vegetation - differentiation, dynamics and transformations (pp. 251-256). Poznań: Wydawnictwo Naukowe UAM.

Czylok, A., Rahmonov, O. \& Szymczyk A. (2008). Biological diversity in the area of quarries after sand exploitation in the eastern part of Silesian Upland. Teka Komisji Ochrany Ksztaltowania Środowiska Przyrodniczego, OL PAN, 5A, 15-22.

Fromm, A., Jakob, S. \& Tischew S. (2002). Sandy grassland in former mining areas. Nat. Schutz Landschplan., 34, 45-51.

Gómez-Heras, M., Smith, B.J. \& Fort R. (2006). Surface temperature differences between minerals in crystalline rocks: Implications for granular disaggregation of granites through thermal fatigue. Geomorphology, 78, 236-249. DOI 10.1515/sggw-2015-0036.

Hollósy, F. (2002). Effects of ultraviolet radiation on plant cells. Micron, 33, 179-197. DOI: 10.1016/S0968-4328(01)00011-7. Hui, R., Li, X., Chen, C., Zhao, X., Jia, R., Liu, L. \& Wei Y. (2013). Responses of photosynthetic properties and chloroplast 
ultrastructure of Bryum argenteum from a desert biological soil crust to elevated ultraviolet-B radiation. Physiol. Plant., 147, 489-501. DOI: 10.1111/j.1399-3054.2012.01679.x.

Kejna, M., Uscka-Kowalkowska, J., Araźny, A., Kunz, M., Maszewski, R. \& Przybylak R. (2014). Spatial differentiation of global solar radiation in Torun and its suburban area (central Poland) in 2012. Bulletin of Geography, Physical Geography Series, 7(1), 27-56. DOI: 10.2478/bgeo-2014-0002.

Kidron, G.J. (2010). The effect of substrate properties, size, position, sheltering and shading on dew: An experimental approach in the Negev Desert. Atmospheric Research, 98, 378-386. DOI: 10.1016/j.atmosres.2010.07.015.

Kidron, G.J, Vonshak, A., Dor, I., Barinova, I. \& Abeliovich A. (2010). Properties and spatial distribution of microbiotic crusts in the Negev Desert, Israel. Catena, 82, 92-101. DOI: 10.1016/j.catena.2010.05.006.

Kidron, G.J., Starinsky, A. \& Yaalon D.H. (2014). Cyanobacteria are confined to dewless habitats within a dew desert: Implications for past and future climate change for lithic microorganisms. J. Hydrol., 519(Part D), 3606-3614. DOI: 10.1016/j.jhydrol.2014.11.010.

Kruczała, K. (2000). Atlas of climate the voivodship of the Śląsk (in Polish). Katowice: IMGW.

Li, X.R., Tian, F., Jia, R.L., Zhang, Z.S. \& Liu L.C. (2010). Do biological soil crusts determine vegetation changes in sandy deserts? Implications for managing artificial vegetation. Hydrological Processes, 24, 3621-3630. DOI: 10.1002/hyp.7791.

Li, Y., Gao, Y., Zhang, L. \& Su Z. (2014). Responses to UV-B exposure by saplings of the relict species Davidia Involucrata Bill are modified by soil nitrogen availability. Pol. J. Ecol., 62, 101-110. DOI: 10.3161/104.062.0110.

Machowski, R. (2010). Transformations of geosystems of water reservoirs originated in subsidence depressions (a case study of the Katowice Upland) (in Polish). Katowice: Wyd. Uniwer. Sląskiego.

Michalska, B. (2011). Tendencies of air temperature changes in Poland (in Polish). Prace i Studia Geograficzne, 47, 67-75.

Nowak ,T., Urbisz, A, Kapusta, P. \& Tokarska-Guzik B. (2011). Distribution patterns and habitat preferences of mountain vascular plant species in the Silesian Uplands (southern Poland). Pol. J. Ecol., 59(2), 219-234.

Oke, T.R. (1999). Urban environments. In W.G. Bailey, T.R. Oke \& W.R. Rouse (Eds.), The surface climates of Canada (pp. 303-327). Montréal: McGill-Queen's University Press.

Paszyński, J. \& Miara K. (1994). The atlas of the Republic of Poland (in Polish). Warszawa: Główny Geodeta Kraju.

Paszyński, J., Miara, K. \& Skoczek J. (1999). The energy exchange at the earth-atmosphere boundary as a base for topoclimatological mapping (in Polish). Dokumentacja Geograficzna, 14, 1-169. http://rcin.org.pl

Pełka-Gościniak, J., Rahmonov, O., Szczypek, T. \& Wach J. (2007). The influence of aeolian factor on circulation of sandy material in the sandpits of Silesian Upland (southern Poland). Annales Geographicae, 40 (1), 57-69.

Rahmonov, O. (2000). The evolution and regeneration of eco-systems in Błędów "Desert" (Southern Poland) - undergone of medieval ecologiacal disaster. Geographia, Studia et Dissertationes, 25, 61-72.

Rahmonov, O. (2007). Relations between vegetation and soil in initial phase of succession in sandy areas (in Polish). Katowice: University of Silesia.

Rahmonov, O. \& Kin N.O. (2007). Role of allochthonous substance in initial stage of succession. Acta Geographica Silesiana, 1, 53-60.

Rahmonov, O. \& Piątek J. (2007). Sand colonization and initiation of soil development by cyanobacteria and algae. Ekológia (Bratislava), 26(1), 52-63.

Rahmonov, O. \& Szymczyk A. (2010). Relations bet ween vegetation and soil in initial succession phases in post-sand excavations. Ekológia (Bratislava), 29(4), 412-429.

Rahmonov, O., Caputa, Z. \& Kłys G. (2002). The biogeocenosis formation on the area with different topography. In D. Kereković (Ed.), GIS Odyseey (pp. 216-224). Zagreb: Hrvatski Informaticki Zbor.

Rahmonov, O., Malik, I. \& Orczewska A. (2004). The influence of Salix a cutifolia Willd. on soil formation in sandy areas. Polish Journal of Soil Science, 37(1), 77-84.

Szczypek, T. \& Wach J. (1999). Human impact and development of a modern scarp dune. In W. Schirmer (Ed.) Dunes and fossil soils (pp. 177-186). LIT Verlag.

Tyc, A., Czylok, A. \& Rahmonov O. (1999). Human impacts and spontaneous regeneration of a karst-aeolian ecosystem in anthropogenic desert near Olkusz (Silesian Upland, Poland). Acta Geographica, 26, 70-77.

Wolf, L., Rizzini, L., Stracke, R., Ulm, R. \& Rensing S.A. (2010). The molecular and physiological responses of Physcomitrella patens to ultraviolet-b radiation. Plant Physiol., 153, 1123-1134. DOI: 10.1104/pp.110.154658.

Xie, Z., Wang, Y., Liu, Y. \& Liu Y. (2009). Ultraviolet-B exposure induces photooxidative damage and subsequent repair strategies in a desert cyanobacterium Microcoleus vaginatus Gom. Eur. J. Soil Biol., 45, 377-382. DOI: 10.1016/j. ejsobi.2009.04.003. 